\title{
A new Surgical Technique: Transvesical Prostate Resection
}

\author{
Hakan Türk ${ }^{1}$, Erkan Arslan ${ }^{2}$ \\ ${ }^{1}$ Department of Urology, Evliya Celebi Training and Research Hospital, Kutahya, Turkey; ${ }^{2}$ Department \\ of Urology, Harran University Medical School, Sanliurfa, Turkey
}

\section{ABSTRACT}

Objectives: Surgical treatment is indicated in patients where medical therapy fails to prove beneficial or in patients who develop complications related with bladder outlet obstruction. In our study, we developed a new surgical technique which can be defined as Transvesical Resection of Prostate (TVRP) without using the urethra. This method was previously described in our articles (1).

Materials and Methods: A 62-years-old male patient, using an alpha blocker agent for 5 years, reported increased discomfort with urination. His findings were as follows: PSA: $1.2 \mathrm{ng} / \mathrm{dL}$, prostate volume: $45 \mathrm{cc}$, digital rectal examination: benign, IPSS: 30, QoL: 5, Qmax: 6, urine volume: $225 \mathrm{cc}$, post-mictional residue: 65 cc. Eventually the patient was informed and prostate resection decision was made.

Results: Suprapubic catheter was removed 1 day after surgery and the patient was discharged. Urethral catheter was removed 4 days after urine output became clear. No complications developed after the operation. At postoperative 1st month, Qmax was 22, urine volume was $260 \mathrm{cc}$, post-mictional residue was $40 \mathrm{cc}$, IPSS was 8, QoL was 1, and the pathology was benign prostate tissue.

Conclusions: Urethral stricture is one of the most important postoperative complications of TURP. The incidence of urethral stricture is reported between 2.2\% and 9.8\% in different series (2-5). In this technique which we developed, urethra is not used and prostate is removed through the bladder, similar to open prostatectomies. For this reason, we suggest that it has an advantage over TURP, regarding urethral stricture development.

\section{ACKNOWLEDGMENT}

The authors thank to Zorlu Ferruh, MD for his contributions to this work.

\section{ETHICS COMMITTEE APPROVAL}

The Institutional Review Board approved this study

\section{CONFLICT OF INTEREST}

None declared.

\section{ARTICLE INFO}

\section{Hakan Türk}

https://orcid.org/0000-0002-4559-301X

Available at: http://www.intbrazjurol.com.br/video-section/20180488_Turk_et_al Int Braz J Urol. 2019; 45 (Video \#X): 1279-80 


\section{REFERENCES}

1. Türk H, Ün S, Arslan E. A new surgical technique: transvesical resection of prostate - case series. Int Braz $\mathrm{J}$ Urol. 2018;44:1023-31.

2. Kuntz RM, Ahyai S, Lehrich K, Fayad A. Transurethral holmium laser enucleation of the prostate versus transurethral electrocautery resection of the prostate: a randomized prospective trial in 200 patients. J Urol. 2004;172:1012-6.

3. Arma an A, Soyupek S, Ho can M, Perk H, Serel A. Comparison of the efficacy of internal urethrotomy and benique dilations in the management of recurrent anterior and posterior urethral strictures. Turk J Urol 2006;32:404-10.
4. de la Rosette JJ, Alivizatos G, Madersbacher S, Perachino M, Thomas D, Desgrandchamps F, de Wildt M; European Association of Urology. EAU Guidelines on benign prostatic hyperplasia (BPH). Eur Urol. 2001;40:256-63; discussion 264.

5. Atalay $A$, Küçükpolat $S$, Tokta $G$, Ünlüer $E$, Koçan $H$, Co kun E. Comparison of transurethral resection (TURP) and transurethral plasmavapourasation (TUVAP) of prostate in benign prostatic hypertrophy patients by using Plasmakinetic tissue treatment systems. Turkish Journal of Urology. 2007;33:308-16
Submitted for publication:

July 17, 2018

Accepted after revision:

April 14, 2019

Published as Ahead of Print:

May 20, 2019

\section{Correspondence address:}

Hakan Türk, MD

Department of Urology

Evliya Celebi Training and

Research Hospital, Kutahya

Kutahya, 43100, Turkey

Telephone: + 90555 551-6885

E-mail: hkntrk000@hotmail.com 